\title{
Latinx Family Engagement in Schools and Surrounding Communities: Assessing the Impact of Parent (and Other Family Member) Development on Improving Student Educational Outcomes at Gene Ward Elementary School
}

\author{
Rosemary Q. Flores ${ }^{1}$, Phyllis Morgan ${ }^{2}$, Linda Rivera ${ }^{3}$ and Christine Clark ${ }^{4, *(D)}$ \\ 1 School of Public Policy and Leadership, University of Nevada, Las Vegas, NV 89154, USA; \\ rosemary.q.flores@gmail.com \\ 2 Gene Ward Elementary School, Clark County School District, Las Vegas, NV 89119, USA; \\ pamorgan@interact.ccsd.net \\ 3 Lower Colorado Region of the U.S. Bureau of Reclamation, Department of the Interior, \\ Boulder City, NV 89005, USA; lrivera@usbr.gov \\ 4 Teaching and Learning, University of Nevada, Las Vegas, NV 89154, USA \\ * Correspondence: chris.clark.unlv@me.com; Tel.: +1-702-985-6979
}

Received: 10 April 2019; Accepted: 23 May 2019; Published: 18 June 2019

\begin{abstract}
This article examined the success of broadly defined family engagement activities of Latinx parents of students at Gene Ward Elementary School. Gene Ward Elementary School is a part of the Clark County School District in Las Vegas, Nevada. This article is based on a larger study of parent and family member participants in these activities at 25 district schools between 2003 and 2012.
\end{abstract}

Keywords: Latinx family engagement; family engagement in schools; race; education

\section{Introduction}

Parent and Latinx parent involvement programs have tended to focus on heteronormative and/or biological definitions of parents, as well as on parental development exclusively or primarily on directly impacting student educational performance [1,2]; for example, teaching a mother and father to regularly communicate high educational expectations to their children. In the original study on which this article is based, the work to engage families, particularly Latinx families-where family is broadly defined to not just include parents (same sex, formally and informally adoptive, etc.), but also older siblings, extended family members, and variously defined others (close friends, community members, among others) - revealed that improved student performance is more predictable when whole families are meaningfully engaged (not just "involved"), and parents' (broadly defined) own personal, academic, and professional development is made more central [3]. For example, emphasizing and supporting parents' educational achievement may, in turn, lead their children to finish homework assignments more reliably than does simply focusing parents on supervising their children's homework completion.

\section{Methods}

Participants in the original study were drawn from the 500 participants (2003-2012) of the Clark County School District (CCSD)-endorsed, but community-based, specific, but broadly defined family engagement activities implemented in 25 district schools [3]. This study used a mixed research design in seeking to determine the nature of the relationship between robust Latinx family engagement and their children's school success. Types of, and trends in, parental and family engagement before, 
during, and following their involvement in the specific, but broadly defined family engagement activities at focus were investigated to establish the impact of participation on student academic outcomes. Student academic achievement, demarcated by key educational outcomes tracked by CCSD (e.g., student attendance rates, homework completion rates, grades, grade level progression rates (retention), graduation rates, and college attendance rates), were evaluated prior to, concurrent with, and after parental participation in the family engagement activities. The academic achievement of a comparable group of students (matched on school, grade, gender, ethnicity, English language proficiency, special education status, and eligibility for free or reduced lunch), whose parents did not participate in these activities, were analyzed comparatively. Constant comparative analysis of the qualitative data (including for time sequencing and to establish causality), as well as mixed factorial analysis of variance (ANOVA), treatment and comparison group (counterfactual) analysis, and Chi Square tests $\left(\mathrm{X}^{2}\right)$ of significance of the quantitative data, was undertaken. The overarching grounded theory orientation of the proposed study enabled integrated analysis of all the data.

In this article, we review the development of, and takeaways from, Latinx family engagement at Gene Ward Elementary School.

\section{Background}

I am humbled by the accomplishments and self-advocacy of a community of families that at one time remained silent. The families who have become engaged in our school and related community activities have found ownership in Gene Ward Elementary as "theirs." They are the people I count on to lead the way in voicing family concerns and dreams for their children (Phyllis Morgan, personal communication, 15 October 2010).

Gene Ward Elementary is an "at-risk," Title I, inner-city school in Las Vegas, Nevada, serving student prekindergarten through fifth-grade students ([4], 2003-2012). Like many schools in the CCSD, the number of students in the school at any given time is over 700, much larger than most elementary school campuses across the nation (NRC, drilled to Demographic Profile (by academic year)). Further, over 85 percent of Gene Ward students fall below the poverty line, and the majority speak English as a second language (NRC, drilled to Demographic Profile (by academic year)). Most (70 percent) of the students who speak English as a second language speak Spanish as their first language, although there are 19 other languages spoken as a first language other than English on the Gene Ward campus (NRC, drilled to Demographic Profile (by academic year)).

The uniqueness of the Gene Ward Elementary student population made family engagement central in the staffs' efforts to improve student achievement. Phyllis Morgan worked at Gene Ward Elementary School for over 15 years, first as Assistant Principal under the leadership of Principal Maria Chávez, and subsequently as its Principal. Together, Chávez and Morgan supported the development of an array of specific, but broadly defined family engagement initiatives to meaningfully involve families in the school community in order to improve student achievement. These activities centered around monthly gatherings at the school, during which a range of personal, social, academic, and professional topics were explored. These topics included family leadership, navigating the public school system (e.g., reading report cards, understanding Grade Point Averages (GPAs), Advanced Placement (AP) and college access test preparation) and building relationships with teachers (e.g., parent-teacher conferences, Parent Teacher Associations (PTAs), Parent Advisory Councils (PACs), School Improvement Teams, (SITs), school governance, dress codes), conflict resolution, accessing college taking and passing high school Graduate Equivalency Diploma (GED) exams, credit recovery programs, understanding charter schools, writing and following personal and family action plans, understanding Title 1 and Title IX, establishing and operating home businesses, civic engagement and public service (volunteerism and giving back), immigration and citizenship pathways, taking and passing citizenship tests, working with police, English as a Second Language (ESL), taking and progressing in English as a second language courses, human psychology, bilingualism/biculturalism, understanding school budgets and improvement plans, accessing community resources, and finding and using voice (e.g., speaking 
up and out, speaking through fear, being heard). During these monthly gatherings, other activities were planned and then carried out. For example, childcare and parallel youth engagement programs were established to increase adult freedom/flexibility to engage, food was provided (which involved fundraising activities to build a food budget) to increase participation and make the gatherings more social, tours of Southern Nevada colleges and universities were undertaken, meetings with city officials to address neighborhood safety, cleanliness, and community facility/green space access and use were held, and a resource referral service was established (e.g., for individual and/or family counseling, for academic tutoring, for preteen and teen initiatives (e.g., referrals to competitive/selective extracurricular activities, service learning opportunities, transition to college programs), and, for parent self-help enterprises (e.g., referrals to small business enterprise programs, entering and completing higher education credentialing programs).

\section{Central Research Question and Its Significance}

The central research question that the original study investigated is: What is the impact of Latinx family engagement on student educational outcomes? This research question is significant because it challenges long-standing existing thinking about the relationship between narrow definitions of parents and of parental involvement and student academic achievement-namely that student performance improves when parents are only or mostly directly focused on improving it and it alone [1,5-9]. The study revealed that more effective approaches for building student success in schools are those that focus on parental and family participation in the democratic life of their local community, including in their children's school(s).

\section{Literature Review}

Latinx students are more likely to be in below grade-level classes, less likely to participate in preand after-school programs, more likely to leave school sooner (stop out, opt out, drop out, get pushed or kicked out) and in greater numbers, and more likely to have lower literacy and English literacy rates than students from all other racial/ethnic groups (President's Advisory Commission [10]). Yet, Latinx students are supported at home in ways that typically result in very high academic achievement in majority student populations $[5,7,11]$.

Cultural Ecological Theory (CET) has been employed to explore the cultural conflicts that emerge as minoritized groups seek to successfully negotiate the Eurocentric cultural norms embedded in U.S. schools [12-15]. These norms do not engender recognition of Latinx family engagement in their children's education because the manners of expression of this engagement are culturally informed; for example, the Eurocentric culture of most schools encourages competition, whereas the home culture of many Latinx students emphasizes cooperation.

Critical Race Theory (CRT) in education has been used to examine the sociopolitical consequences of racism in educational settings in the United States [16-19]. Eurocentric culture is predicated on two racist assumptions, one covert and one overt. The covert assumption is that acculturation to Eurocentric norms is "wise": the overt assumption is that assimilation to these norms should be desired. Thus, Latinx students who come to school expressing eagerness to learn in Latinx culturally reflexive ways are often perceived to be less capable and taught (or not taught) accordingly. Likewise, parents and other family members who seek out engagement in their children's schools in manners that reflect their Latinx cultural identities are often met with indifference, or worse, hostility.

While CET and CRT have provided insights into the experiences of Latinx students and their families in educational settings, Culture-Centered Theory (CCT) has been engaged in the development of pragmatic strategies for parlaying these insights into concrete solutions [6,20-22]. To reconcile the contradiction between the educational support provided to Latinx students by their families, and these students' still-persistent lack of academic achievement, CCT emphasizes the need for highly culturally relevant and responsive and otherwise robust schooling interventions like Latinx-focused parent involvement programs $[1,2,8,9,23,24]$. 
Unfortunately, most PK-12 schools have not yet built relationships with Latinx parents and families and, therefore, not built on the relationships among Latinx family members that are necessary to bring the very high academic achievement of Latinx students to fruition [1,2]. Further, Latinx parents and families have found initiating involvement in their children's PK-12 schools challenging, largely because they do not feel welcomed in seeking to do so [8,9].

However, even when Latinx-focused "parent involvement" (as opposed to family engagement) programs are highly culturally relevant and responsive and otherwise robust, if they focus mostly or exclusively on improving student academic achievement, they have yielded only incremental improvement in student attendance, homework completion rates, and overall educational advancement $[1,3,11]$. Outcomes from the original study revealed that Latinx family engagement in schools and surrounding communities yields more substantive student academic improvement and inclination toward higher education. Accordingly, this article considers these outcomes to further highlight the extent to which, how, and why the democratic participation of Latinx families in school and local communities brings about more extensive and durable improvements in their children's educational success. The goal of this article is to aid in the development of new bases of knowledge from which greater improvements in Latinx student educational outcomes can be realized.

\section{Conceptual Framework}

This study employs the concept of participatory democracy in examining family engagement in the democratic functioning of schools and the communities that host them. According to Fishkin [25], when constituents of democratic systems broadly participate in the operation those systems, their quality of life improves. Building on Fishkin's premise, a Latinx student's educational performance may be significantly increased by their parents' civic involvement because of how this involvement is perceived to improve, and/or actually improves, the family's overall quality of life.

\section{Roots}

Like so many of the students who attend my school, three of my four grandparents were immigrants to the United States and they all spoke a language other than English when they came to this country. This is one of the main reasons I stayed at Gene Ward Elementary School for so long: I understood my school community. My grandparents' efforts to survive and thrive as new immigrants to the United States-such as advocating for their child, seeking out and attempting to use community resources, or building a supportive network-were blocked by cultural and linguistic barriers. I often wonder how my grandparents', parents', and my family's life would be different today if my family had had access to the kinds of family engagement activities we established at Gene Ward. You see, these activities all but erased the blocks and barriers, and they did so not just for one child or one family, but for generations (Phyllis Morgan, personal communication, 15 October 2010).

Intentional family engagement efforts began at Gene Ward Elementary in 2005 when the school's English Language Learner (ELL) program obtained a grant enabling it to have one of its teachers dedicated to promoting family engagement in the school. Chávez and Morgan were strong supporters of the idea to use this grant money for this purpose, having long recognized that Latinx parents lacked the most "voice" in the school. Prior to 2005, Chávez and Morgan noted that although Latinx parents were often involved in school events and came to parent-teacher conferences, it was extremely difficult to get them to take on leadership roles within the school. They found themselves scrambling to find parents, any parents, but especially Latinx parents, to join the PTA or SIT. Further, when school board members would hold meetings for parent representatives, or Title I district meetings called for parent representatives, it was difficult to find any parent willing to attend, again, especially a Latinx parent.

Teacher Maria Cieslak was chosen by Chávez and Morgan to dedicate her time to family engagement activities because of her compassion for the parent community, her ability to speak three languages-Polish, English, and Spanish-her expertise as a National Board Certified English as a Second Language (ESL) Teacher, and her ability to support the learning needs of the very diverse 
group of parents who were expected to participate in these activities at the school. Around the same time that Cieslak was beginning to develop family engagement activities at Gene Ward, Chávez and Morgan hired bilingual (Spanish and English) Instructional Assistant Norma Juárez for one of the school's Title I Pre-K programs, only to discover, shortly thereafter, that she also brought with her extensive family engagement experience. Together, Cieslak and Juárez developed Gene Ward Elementary School's family engagement activities. As noted above, these activities included monthly family engagement gatherings that, when Chávez and Morgan first attended, took them by surprise because attendees were learning about Maslow's [26] hierarchy of needs or in deep discussion about future goals for themselves as individuals, as well as for their families. Chávez and Morgan found these gatherings to be more like college courses than any "parent training" they had ever come across previously. Accordingly, they were very impressed with the higher-order thinking and learning being demonstrated.

Space, budget, and leadership development considerations also factored into the development of the family engagement activities at Gene Ward Elementary. In 2009, five years into Gene Ward's intentional development of family engagement activities, the school was fortunate to have enough facility space to designate two rooms almost exclusively for these activities, including for childcare, as well as various meetings with both adolescents and adult family members. The same year, school staff developed a plan for how it would engage veteran participants in the family engagement activities to start leading those activities so that these activities could be engaged "by families for families." This required Gene Ward staff to learn how to think differently about school governance and, ultimately, to do a lot of "letting go" so that family members could assume responsibility for school leadership.

\section{Growth}

Perhaps not surprisingly, the staff at Gene Ward Elementary School witnessed some very remarkable changes that they expressly attribute to their intentional family engagement efforts. As mentioned previously, prior to the implementation of the family engagement activities in 2005, Gene Ward had no parent volunteers willing to take on any leadership roles. By 2010, after five years of intentional family engagement, the Gene Ward PTA Board of Directors was comprised exclusively of family member participants in these activities. Likewise, Gene Ward's SIT parent member slots, CCSD PAC parent representative slots, and CCSD Title I Parent Meeting parent representative slots were filled, and filled exclusively, by family member participants in these activities.

Parent and family member volunteerism in general also dramatically increased on the Gene Ward campus. Parents and family members assisted, on a daily basis, to support the learning environment in classrooms, on the playground, in the multipurpose activity room, and in el Jardin del Sol—the school's two-acre garden.

Parents and family members also found and began using their "voice" at Gene Ward. In 2004, Morgan vividly recalls conducting staff and family member surveys to garner support for implementing a student uniform policy at the school based on her review of the then-current research about the potential positive impacts of school dress codes on student performance. CCSD policy required a minimum of $80 \%$ support from parents and staff to change school protocols in this regard, but to Morgan's dismay, the surveys indicated a lack of parental support for a student uniform policy. In contrast, in 2010, a group of parents led by family member participants in the school's family engagement activities conducted their own research on student uniforms and academic performance and subsequently demanded that Gene Ward implement a standard dress code for all students. These participants held several meetings. They chose the components of the "Student Standard Attire," and informed other parents and family members about their plans. When put to a public vote in April 2011, the measure passed. When parents own knowledge, everyone's-parents, teachers, school staff, and, especially students-path to educational success is enhanced.

Gene Ward's parent and family member voice also helped keep the school safe (and from costly damage and loss). The Las Vegas Metropolitan Police Department offered a parent training in 2007. 
The parents who chose to attend that training were, once again, family member participants in the school's family engagement activities, as well as their nonparticipant spouses. At around that same time, Gene Ward Elementary had been experiencing a series of late-night and weekend break-ins, resulting in vandalism and theft. Shortly following the training, one of the training attendees saw an unfamiliar man on a Gene Ward rooftop and called the police to report it. The man on the rooftop was determined to be the person breaking into the school; he was arrested and prosecuted. Later it was revealed that this man was stealing the copper wire used for the school's computer systems to sell. The district was able to have the wire replaced quickly so that Gene Ward students did not experience any interruption in their computer access. The training attendee who reported the unfamiliar man to the police later shared with Gene Ward staff that, prior to participating in the Police Department parent training, he would not have made that call to the police, both because he feared police and believed that they would not take him seriously. However, because of his positive experience in the Police Department parent training, he placed the call. Thankfully, this family member participant in the school's family engagement activities is not unique; it has been repeated several times by other observant participants who witnessed several similar situations and opted to call for help. Gene Ward Elementary School is a safer place for its students to learn and grow because meaningfully engaged family members have found and use their voice.

Increased family camaraderie also became very palpable at Gene Ward Elementary as a result of their family engagement work. Families befriended and supported each other and school staff in ways Morgan never imagined possible. For example, in 2006, during Gene Ward's second year of intentional family engagement activity programming, parent and family member activity participants decided to take a GED preparation course. Many of them did not have their own transportation to get themselves to and from the course sessions; fortunately, those who did have vehicles offered to carpool so that all who were interested could take the course. In another instance this same year, a participating mother-young, with three children, and fleeing abuse-found herself unemployed and homeless. In an instant, this mother and her children were taken in and cared for by members of the Gene Ward "extended family, family." This mother became gainfully employed and, therefore, able to care for her three daughters on her own. The pride she came to exude in her ability to provide for her family, coupled with the gratitude she expressed for those who cared for her and her children in her time of need, cannot be measured, but they were felt at the deepest levels by all members of the Gene Ward Elementary School community.

\section{Wings}

Over time, family engagement activity-focused work at Gene Ward grew into a community-based family engagement movement in which, increasingly, participants learned from each other's successes. As previously noted, at monthly gatherings, family members listened to guest speakers on a range of topics, especially on the topic of how to improve education in Nevada.

\subsection{Parent Educational Advocacy}

Inspired by speakers on education, five active parent participants attended a legislative hearing on education funding and potential cuts to that funding; one spoke out against the cuts. As a result of the efforts of these parents, a state legislative committee was formed to bring parents together to formally engage educational issues in subsequent legislative sessions, and CCSD's central administration augmented its family engagement work, including by hiring three of the parents.

\subsection{Continuing Education}

More than 30 immediate and extended family members obtained their GED. One went on to pursue vocational education to become a licensed Cosmetologist. Three enrolled in higher education-two at the College of Southern Nevada (CSN, a community college) and one at Nevada State College (NSC). Two of these three received scholarships from the Southern Nevada Hispanic Employment 
Program (SNHEP) to support their higher educational goals. Numerous participants enrolled in and continuously attend classes in English as a second language. Many others have enrolled in nutrition classes.

Also in the education arena, many participating mothers took advantage of private funding, obtained through a grant, to attend the "Life Re-Design Plan Madrinas Retreat," sponsored and hosted by the University of Nevada, Reno Cooperative Extension, and co-sponsored by NSC, SNHEP, Bilingual Consulting Services (a local small business), and the MGM MIRAGE. Developed by Dr. Myrna Araneta, an organizational systems psychologist, 15 mothers attended the Retreat in 2007 as a single cohort, and 17 mothers attended the Retreat in 2010 in two cohorts-one comprised of those who previously attended (to build on their prior learning), and one comprised of new attendees. The Retreat engages mothers in the development and implementation of more comprehensive action plans to ensure productive futures for their families.

\subsection{Connecting Education to Entrepreneurship}

A family engagement partnership was also established with Nevada Micro-Enterprise to provide business seminars to participating mothers interested in beginning home businesses dedicated to supporting their families' educational goals. Over 25 mothers attended and five have already started their home businesses.

\subsection{Youth Educational Advocacy}

At a 2009 monthly gathering, the idea to establish a forum for youth educational advocacy was raised. In March 2010, 22 participating adolescent family members of Gene Ward students established a youth council with a three-pronged educational mission: accountability to family and self, service learning, and leadership. Meeting every two weeks, the youth council's first priority was to secure charitable funding to support activities that supported achievement of their mission.

Thereafter, the youth council established: (1) a partnership with the City of Las Vegas directed at neighborhood beautification; this partnership led several council members to join neighborhood councils; and, (2) mentoring relationships with college students pursuing degrees in the council members' areas of academic and professional interests. In furtherance of the council's educational mission, all council members attended the University of Nevada-Reno's Cooperative Extension "Anahuac Program," a High School dropout prevention initiative, and volunteered, through the Las Vegas Convention and Visitors Authority (LVCVA), to help staff local conferences in order to learn about conference topics, as well as how conferences are organized and operated.

\section{Conclusions}

The friendship we have with other families makes us realize that we are not alone; that there are more families such as ours and they all have the same purpose to struggle for the best. Thank you from my heart for your efforts and interest in bettering our community (parent, personal communication, 9 December 2010).

Educational achievement is often seen as the key to securing access to full participation in democracy for historically underrepresented racial, ethnic, gender, and economic groups in the United States. Findings from the original study on which this article is based challenge the developmental linearity implied in oversimplifying the relationship between education and social opportunity. Instead, these findings reveal that civic engagement fosters, or even drives, educational accomplishment, and that the relationship between involvement in community life and commitment to educational advancement is more reciprocally complex than typically acknowledged. While education has indeed opened doors to robust citizenship in the United States, it has not done so as quickly and predictably as is often promoted through references to "the American dream." This article examined how and why Latinx family engagement in a school and surrounding community may more expediently and reliably translate into improved student educational outcomes, than does mere parent involvement focused 
only or largely on their children's performance in school. Accordingly, this article extends the existing research literature on parent and Latinx parent involvement programs by documenting how and why Latinx family engagement work may be more successful in bringing about improved Latinx student educational outcomes when its parental development focus prioritizes the holistic growth of whole families brought about by their varied engagement in school and the community at large.

Author Contributions: Conceptualization, R.Q.F., P.M., L.R. and C.C.; methodology, R.Q.F. and C.C.; validation, R.Q.F., P.M., L.R. and C.C.; formal analysis, C.C.; investigation, R.Q.F., P.M. and L.R.; data curation, R.Q.F., P.M., L.R. and C.C.; writing - original draft preparation, R.Q.F., P.M., L.R. and C.C.; writing-review and editing, C.C.; visualization, R.Q.F., P.M., L.R. and C.C.; project administration, R.Q.F.

Funding: This research received no external funding.

Conflicts of Interest: The authors declare no conflict of interest.

\section{References}

1. Tinkler, B. A Review of Literature on Hispanic/Latino Parent Involvement in K-12 Education; Document Numbers ED 469134 and RC 023599; United States Department of Education, Office of Educational Research and Improvement, Educational Resource Information Center (ERIC): Washington, DC, USA, 2002.

2. Zarate, M. Understanding Latino Parental Involvement in Education: Perceptions, Expectations, and Recommendations; Tomás Rivera Policy Institute, University of Southern California: Los Angeles, CA, USA, 2007.

3. Clark, C.; Flores, R.; Rivera, L.; Biesinger, K.; Morgan, P. We make the road by walking: The family leadership initiative in Las Vegas. In Breaking the Mold of Education for Culturally and Linguistically Diverse Students: Innovative and Successful Practices for 21st Century Schools; Cohen, A., Honigsfeld, A., Eds.; Rowman and Littlefield: New York, NY, USA, 2012.

4. Nevada Report Card (NRC). Demographic Profile. 2003-2012. Available online: http://nevadareportcard.nv. gov/DI/nv/clark/gene_ward_elementary_school/2018 (accessed on 25 January 2019).

5. Chrispeels, J.; Rivero, E. Engaging Latino families for student success: How parent education can reshape parents' sense of place in the education of their children. Peabody J. Educ. 2001, 26, 119-169. [CrossRef]

6. Delgado-Gaitán, C. Involving Latino Families in Schools: Raising Student Achievement through Home-School Partnerships; Corwin Press: Thousand Oaks, CA, USA, 2004.

7. Guerra, P.; Valverde, L. Latino communities and schools: Tapping assets for student success. Princ. Leadersh. 2007, 8, 40-44.

8. Quezada, R.; Díaz, D.; Sánchez, M. Involving Latino parents. Leadership 2003, 33, 32-34.

9. Quiocho, A.; Daoud, A. Dispelling myths about Latino parent participation in schools. Educ. Forum 2006, 70, 255-267. [CrossRef]

10. President's Advisory Commission on Educational Excellence for Hispanic Americans. Our Nation on the Fault Line: Hispanic American Education, a Report to the President of the United States, the Nation, and the Secretary of Education; White House Initiative on Educational Excellence for Hispanic Americans: Washington, DC, USA, 1996.

11. Nieto, S.; Rivera, M. (Eds.) Charting a New Course: Understanding the Sociocultural, Political, Economic, and Historical Context of Latino/A Education in the United States; The Spencer Foundation: Chicago, IL, USA, 2010.

12. Foster, K. Coming to terms: A discussion of John Ogbu's cultural-ecological theory of minority academic achievement. Intercult. Educ. 2004, 15, 369-384. [CrossRef]

13. Luna, N. Clark County Dropout Needs Assessment Report: Community Readiness Data Collection Process to Address Latinx School Dropout; University of Nevada Cooperative Extension: Reno, NV, USA, 2008.

14. Ogbu, J. (Ed.) Minority Status, Oppositional Culture, and Schooling; Routledge: New York, NY, USA, 2008.

15. Valdés, G. Learning and Not Learning English: Latino Students in American Schools; Teachers College Press: New York, NY, USA, 2001.

16. Cammarota, J. A social justice approach to achievement: Guiding Latina/o students toward educational attainment with a challenging, socially relevant curriculum. Equity Excell. Educ. 2007, 40, 87-96. [CrossRef]

17. Delgado Bernal, D. Critical race theory, LatCrit theory and critical raced-gendered epistemologies: Recognizing students of color as holders and creators of knowledge. Qual. Inq. 2002, 8, 105-126. [CrossRef] 
18. Dixson, A.; Rousseau, C. Critical Race Theory in Education: All God's Children Got a Song; Routledge: New York, NY, USA, 2006.

19. Ladson-Billings, G.; Tate, W. Toward a critical race theory of education. Teach. Coll. Rec. 1995, 97, 47-68.

20. Howard, T. Culturally relevant pedagogy: Ingredients for critical teacher reflection. Theory Pract. 2003, 42, 195-202. [CrossRef]

21. Wortham, S.; Contreras, M. Struggling toward culturally relevant pedagogy in the Latino/A diaspora. J. Lat. Educ. 2002, 1, 133-144. [CrossRef]

22. Zambrana, R.; Zoppi, I. Latina students: Translating cultural wealth into social capital to improve academic success. J. Ethn. Cult. Divers. Soc. Work 2002, 11, 33-53. [CrossRef]

23. Gay, G. Preparing for culturally responsive teaching. J. Teach. Educ. 2002, 53, 106-116. [CrossRef]

24. Ladson-Billings, G. But that's just good teaching! The case for culturally relevant pedagogy. Theory Pract. 1995, 34, 159-165. [CrossRef]

25. Fishkin, J. When the People Speak; Oxford University Press: Oxford, UK, 2011.

26. Maslow, A. A theory of human motivation. Psychol. Rev. 1943, 50, 370-396. [CrossRef]

(C) 2019 by the authors. Licensee MDPI, Basel, Switzerland. This article is an open access article distributed under the terms and conditions of the Creative Commons Attribution (CC BY) license (http://creativecommons.org/licenses/by/4.0/). 